\title{
A simulation tool for talent management in knowledge-intense firms. An opportunity for HR managers?
}

\author{
Nuria Calvo $\cdot$ María Bastida $\cdot$ Jacobo Feás
}

Published online: 16 January 2013

(C) International Network of Business and Management 2013

\begin{abstract}
This article reviews the consequences of introducing certain policies in consulting firms, from the point of maintaining intellectual capital. Consultancies base the competitive edge of their offering on the knowledge of their professionals, despite the difficulties inherent in depending internally on a resource which may of its own volition choose to leave the company, and depending externally on demand for services. Devising a dynamic simulation tool to aid in decision-making, we found that, while the demand for consultancy services determines the number of consultants required, the knowledge management policies of each organization determine its internal capacity to maintain its intellectual capital within the sector.
\end{abstract}

Keywords Strategy planning · Change management - Consultants · Dynamic simulation - Human resources planning

\section{Introduction}

The issue of managing the talent within their ranks represents a concern for an increasing number of organizations. Over recent years we have seen a proliferation of studies which aim to quantify the value of the "intangible assets" held by the company, and human resources practices have taken on a "strategic" role for

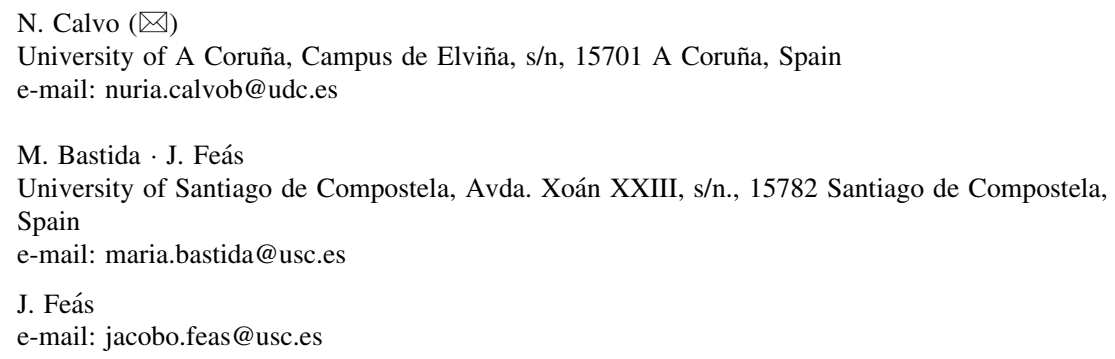


organizations, establishing a direct relationship between the management of professional staff and the achievement of corporate objectives (Table 1).

Literature considers that, to assure the value of professionals to develop and contribute to an increase in the market value of their organization, it is essential that the most appropriate human resources policies be devised, in accordance with demand, competition, and the specific characteristics of employees themselves, to create a "human capital advantage" (Boxall 2006; López Cabrales et al. 2009; Minbaeva 2008). A failure to do this could not only gradually devalue the organization, but also could do so suddenly through the undesired departure of those professionals most valued by the market (Martell and Carroll 1995; Subramony 2009).

Table 1 Literature review

\begin{tabular}{|c|c|c|}
\hline Scientific perception & Authors & Key issues \\
\hline $\begin{array}{l}\text { Resources and capacities as base of } \\
\text { competitive advantage }\end{array}$ & $\begin{array}{l}\text { Rumelt (1984) } \\
\text { Barney (1991) } \\
\text { Peteraf (1993) } \\
\text { Hatch and Dyer } \\
\quad(2004)\end{array}$ & $\begin{array}{l}\text { Intellectual capital, strategic resource for } \\
\text { consultancies }\end{array}$ \\
\hline $\begin{array}{l}\text { Dynamic approach of resource-based } \\
\text { view }\end{array}$ & $\begin{array}{l}\text { Dierickx and } \\
\text { Cool (1989) } \\
\text { Amit and } \\
\text { Shoemacker } \\
(1993) \\
\text { Grant (1996) }\end{array}$ & $\begin{array}{l}\text { Organizational practices as key capacities } \\
\text { base of competitive advantage }\end{array}$ \\
\hline $\begin{array}{l}\text { Intellectual capital as human resources } \\
\text { investment. "Knowledge flows" } \\
\text { management }\end{array}$ & $\begin{array}{l}\text { Warren }(2000 \text {, } \\
\text { 2003) } \\
\text { Watson and } \\
\text { Papamarcos } \\
\text { (2002) } \\
\text { Bueno and } \\
\text { Morcillo } \\
\text { (2002) }\end{array}$ & $\begin{array}{l}\text { Recruiting, selection, professional } \\
\text { development, and retention and } \\
\text { departure practices as key routines for } \\
\text { maintaining the intellectual capital of } \\
\text { consultancies }\end{array}$ \\
\hline HR practices and talent management & $\begin{array}{l}\text { Walton (1985) } \\
\text { Cappelli and } \\
\text { Crocker- } \\
\text { Hefter (1996) } \\
\text { Andersson and } \\
\text { collegues } \\
\text { (2005) } \\
\text { Collings and } \\
\text { Mellahi (2009) } \\
\text { Tarique \& } \\
\text { Schuler (2010) }\end{array}$ & \\
\hline
\end{tabular}


Within this context, for the strategy department at an organization to make an effective contribution to increasing the company's competitiveness, two conditions must apply: first, the organization must incorporate the necessary human skills so as to implement the strategy defined, and second, it must guarantee that human resources programs and practices operate properly, to effectively implement the strategy (Wright and McMahan 1992).

From this perspective, human resources practices may be considered as organizational routines (Grant 1996); in other words, regular and foreseeable models of activity comprising a sequence of coordinated, individual actions, serving as the basis for the organization's capacity to generate and accumulate intellectual capital.

In this context, the proper management of the talent of their professionals represents the raison d'être of companies belonging to the consultancy sector. The knowledge-applied experience ratio of consultancy professionals represents the differential element in the competitive edge of this type of company, requiring planned management of human resources based on professional development, performance management, and the adaptation of both these factors to business strategy (FEACO 2001).

In order to properly take up this challenge, however, two serious difficulties must be faced. First, the company does not enjoy ownership of the knowledge and experience of its professionals, who are free to leave the organization if their expectations are not fulfilled.

Knowledge exchange and management systems, along with other attempts to replicate skills, maintain networks of contacts with former employees or formalize tacit knowledge through formal processes (Nonaka and Takeuchi 1995) and represent attempts to retain part of the intellectual capital of professionals within the heart of the organization, attempts which often, however, fail to replace the skills lost as a result of the departure of such individuals.

Second, the demand for consultancy services is extremely sensitive to the economic instability of the marketplace. Very often, the budgetary allocation for financing advice and consultancy services is the first to be cut by companies in periods of economic stagnation or recession. This situation hugely complicates the management of professionals at consultancy companies, conditioning to a large extent decisions to the creation and maintenance of their intellectual capital, and hence their competitive positioning within the sector.

For the reasons set out above, consideration was given as the main focus of the analysis to the design of a dynamic simulation tool which would make possible an explanation of the consequences of the introduction of certain management policies for professional staff, from the point of view of the creation or destruction of the intellectual capital of a consultancy body.

\section{Definition of the situation to be modeled}

The consultancy business is closely tied to the market's need for talent. A consultant's work begins when a commission is received from a client, who may or may not be informed about the task entrusted. Once the assignment or 
commissioned consultancy service has been completed, the relationship between client and consultant ends, unless a new contract is signed.

The differing organizational structures seen in consultancy companies are the result of their ongoing adaptation to the external demand for services. Management consultancy as a business is based on the provision of expert, qualified professionals, meaning that the cost and management of individuals are the main factors determining the operations and competitive edge of this type of enterprise.

A thoroughgoing analysis of the sector, combined with a survey of senior managers at a number of consultancy firms from 2006 to 2008, allowed us to identify a series of relevant factors in defining the characteristics of the management of professionals at consultancies (Calvo 2011): (a) the existence of a project-based working system, (b) the need to invest a greater quantity of resources than that seen in other sectors in the processes of recruitment and professional development of consultants, (c) the difficulty of maintaining the intellectual capital stored up in experienced (senior) consultants, (d) the high rates of voluntary departure, (e) the internal difficulties generated in situations where the demand for consultancy services is greater than the supply of qualified consultants in place at the organization, forcing companies to take on experienced professionals from the outside market, rather than promoting junior consultants internally, and (f) the influence exerted by the reputation of a consultancy company as a "knowledge organization" in the human resources practices of the organization, both in recruitment and selection and in the rate of departure of its professionals, and consequently the attractiveness of the company within the sector.

Once the most significant factors of the situation to be analyzed had been isolated, a series of policies was drawn up, based on a consensus with the experts consulted, defining the decision-making rules which govern the behavior of the variables defined in the model, as listed below (Calvo 2011):

(1) “A consultancy's demand for consultants is determined by external market factors (sectorial demand) and factors which determine the competitive edge of the organization within the sector (attractiveness of the company).

(2) The processes of recruiting and selecting consultants cover a time period from the point at which vacancies are generated until the point when the chosen candidate begins work.

(3) The make human resources system (Miles and Show 1984) is that most frequently used at management consultancy companies, and involves prioritizing internal promotion over the external selection of experienced professionals, as a general rule.

(4) The process of the professional development of junior consultants takes time, generally lasting between 2 and 5 years on average.

(5) The formal promotion of junior consultants to senior category depends both on the existence of junior consultants available as candidates for promotion and on the existence of vacancies at senior level.

(6) The number of consultants leaving the company is influenced by such wideranging factors as its reputation, the relative salary level of the category and excess workload. 
(7) The number of consultants made redundant is conditioned by the existence of an actual workforce at the company in excess of that required by the market."

Having analyzed the situation to be modeled through a conceptual understanding, we developed a dynamic simulation model capable of representing the repercussions which the policies introduced at such organizations have on their flow of professionals.

The model devised reflected the behavior of the flow of professionals at a consultancy, as a result of the implementation of the talent management policies most often employed within the sector, regarding recruitment and selection, professional development, promotion, and the departure of professionals.

According to the requirements to validate the model structure, we used the historical data related to the flow of consultants, obtained from the Cap Gemini consulting firm (1999-2005), as reference.

In order to validate the model structure, we used the module developed by Oliva (1995), based on the work of Stearman (1998). Oliva (1995) proposes model calibration-the process of estimating model parameters (structure) to obtain a match between observed and simulated structures and behaviors as a form of model testing. The results of validation (correlation coefficient $R^{2}=0.93$; Mean squared error $(\mathrm{MSE})^{1}=0.044$; Bias $\left(U^{\mathrm{M}}\right)=0.14$; Unequal variation $\left(U^{\mathrm{S}}\right)=0.007$; Unequal covariation $\left(U^{\mathrm{C}}\right)=0.84$ ) evidence a good adjustment between the behavior of the referenced data and that simulated by the model.

The purpose of the model was to reproduce the actual behavior of the system (Forrester 1961; Stearman 2000), and thereby establish a useful support tool for executive decision-making processes (Senge 1990), regarding talent management at consultancy organizations. We developed the modeling project to study how the human resources policies which allow a swift adjustment of the workforce to market demand would make the company more attractive within the sector. This model (Fig. 1) analyzed how delays in adjustment HR policies to the change of HR planning objectives or decisions could influence in the flow of experienced consultants and the attractiveness within the sector.

The aspects identified as the most significant in decisions regarding the recruitment and selection of consultants were, on the one hand, the objective percentage distribution of the workforce in terms of junior and senior categories, which will determine the level of intellectual capital offered by the company in comparison with the sector; and the choice, as a general principle, of a make system of human resources (Miles and Show 1984), which establishes that consultancy firms should preferably fill their senior consultant vacancies through the internal promotion of junior consultants available for promotion.

The baseline for the recruiting and selection policy among consultancy companies involves establishing the number of junior and senior consultants their organization is going to need on an annual basis, in accordance with forecast demand. This means that the company will limit the number of staff recruited to the number of vacancies present during the period analyzed, matching the number of

\footnotetext{
${ }^{1} \mathrm{MSE}=1 / n \Sigma \mathrm{l}\left(\mathrm{S}_{\mathrm{t}}-\mathrm{A}_{\mathrm{t}}\right) / \mathrm{A}_{\mathrm{t}}$.
} 


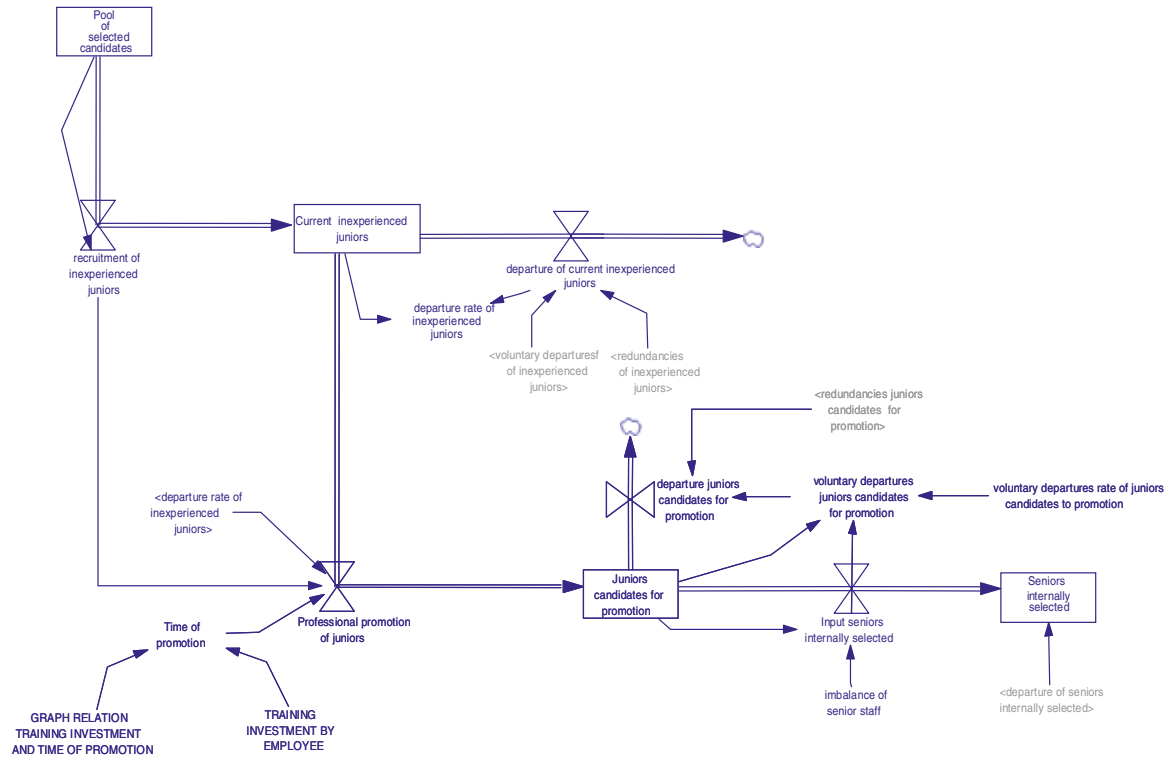

Fig. 1 Flow diagram: professional development for junior consultants

professionals to the external demand detected. The consultancy organizations consider selection to be one of the central strategic planks in their acquisition of intellectual capital, a differential resource which is directly connected to their economic activity. This dictates the specialization and considerable volume of resources dedicated to this process, compared with other sectors. In addition to the high financial costs involved, this also leads to a time lag in the process, ranging between 1 and 3 months in the case of junior consultants, and between 1 and 6 months in the case of senior consultants.

With regard to the professional promotion and development policy for consultants, one of the most characteristic aspects of consultancy firms is their high level of investment in the professional development of their employees. Aware of the importance given by their clients to the quality of the advice services offered and the implementation of projects by their professionals, consultancy firms on average invest more in training and development than organizations belonging to other sectors (Warren 2000; Warren and Kourdi 2003). The figure for investment in training includes both formal training given within and outside the company and knowledge management systems (push, pull, interaction, and expert location applications) (Bonache and Cabrera 2005), along with hours dedicated to coaching provided by other members of the organization, which is the standard practice at consultancy firms.

One of the central planks of the human resources strategy within this sector is its organizational capacity to speed up the acquisition of knowledge and skills by its professionals. This capacity serves as a tool for improving companies which belong to other sectors, through the advice of expert consultants within each field of 
operations. These companies consider it even more important to enable their professionals to learn skills of know how than specific knowledge. However, this practice will make these employees more transferable in the market.

In order to do so, in addition to recruiting and selecting individuals with considerable potential for learning, investments must be made in training programs and professional development. These investments are considerably higher than those incurred by other sectors, through personal training plans, remote training, attendance of specialist programs, and involvement in projects as support staff at no cost to the client, among others, while also facilitating access to knowledge management systems allowing the learning curve to be steepened.

This process will give rise to the creation of consultancy professionals with the talent to take on a lead role on projects, with promotion from junior to senior category generally coming within a period of between 2 and 5 years, depending on the nature of the field of activity and the capacity of the organization, while also swelling the ranks of those junior consultants ripe for promotion to a senior position during the next professional review.

In the situation to be analyzed, a distinction was made between the professional development of junior consultants and their formal promotion to senior consultant through internal recruitment. Although it is often assumed that professional development within this type of organization is generally accompanied by formal promotion to a higher category, the reality of the organizations consulted does not always guarantee this second part of the process. The average time required for a junior consultant without experience to acquire the necessary skills to perform the functions of the senior category varies between 2 and 5 years on average, in accordance with the relative level of investment in training within the sector. Formal promotion to the higher category (internal seniors) requires the existence of junior consultant candidates for promotion. However, this promotion will only take place if vacancies exist at the aforementioned category, which does not always coincide with the development flow of the professionals.

As for the policy for the departure of professionals, the outgoing flow of inexperienced junior consultants and senior consultants is the sum of the redundancies made in each category and the voluntary departures of consultants.

Although the organizational structure of this type of company is based on the constant renewal of junior consultants, the departure of professionals with key skills may represent a significant loss of intellectual capital, thereby impeding the acquisition of a competitive edge by such companies (Godbout 2000). Within this context, the departure of experienced consultants may increase the relative attractiveness of competitor companies. Although according to resources and skills theory the intellectual capital generated by these professionals cannot easily be transferred to other companies (Peteraf 1993), their inclusion as human capital does constitute a necessary factor for the creation of new intellectual capital, as the basis of the future competitive edge of other organizations.

According to a survey conducted of 140 senior consultancy managers, and more than 700 employees, within the sector in Europe and the United States in 2007, those factors seen as having the greatest impact on the departure of professionals at such companies were, in order of relevance: the company's relative salary rates 
within the sector, career development prospects, and problems in balancing professional and family life as a result of overlong working hours (Top Consultant 2007). The professionals queried stated that, on average, they expected to be employed by at least three consultancy organizations during their career, although a positive professional experience could lead them to stay longer at one single organization. This response suggests that, although the high rate of professional staff turnover is a problem endemic to the consultancy sector, organizations can minimize the rate of departure through their own professional management systems.

In the devised model, the figure for the departure of consultants will be determined by the percentage of departures applied during each period, in accordance with the three aspects seen as key: (1) perceived salary level, in relation to the market level in the corresponding sector (Rynes et al. 2004), (2) perceived excess workload (Biswas and Twitchell 1991), reflecting the need for consultants compared with the desired number of consultants during a given period, explaining the pressure of work placed on the actual workforce, and (3) the client's perception of the company's reputation.

The figure for consultant redundancies will be the result of the company's decision to adjust its actual workforce to the number of consultants required, if this latter figure is lower than the total consultant workforce at the organization.

The flow of departures from the sub-category of junior consultant candidates for promotion, as well as being conditioned by the factors considered above, will also be influenced by the perception of the formal promotions made by the company with respect to the portfolio of existing candidates. The greater the number of promotions, the lower the tendency of this category to depart.

Finally, with regard to the flow of demand for consultants, consultancy firms plan the number of consultants required in accordance with the demand forecast from their market share. The percentage allocation between junior and senior categories will be determined by the "knowledge organization" policy which each firm chooses to maintain. However, despite the fact that overall demand in the sector is an external variable, each company has a relative influence in accordance with its attractiveness for the client. In other words, in a market economy, clients may register a greater demand for consultancy projects from certain firms within the sector, rather than considering all organizations on an equal basis.

The company attractiveness variable reflects the market share held by the company within the sector, and this determines its demand for consultants. This is calculated using the service cost and perceived company reputation factors, bearing in mind that each of these has an opposite effect on demand. The joint effect of both factors will determine the resulting market share, described as the attractiveness of the company for the client, which will be key in obtaining the number of consultants required for a given period.

In order to complete the above vision, consideration must be given to the fact that the level of reputation of a company within the consultancy sector is the variable which, to the largest extent, determines the salary level of its consultants. So, an increase in the level of an organization's reputation does not only have a positive influence on its attractiveness, but also determines the salary increases of its professionals. Bearing in mind that salary costs represent the main component in the 
pricing of the services of this type of organization, rising salaries will have a positive repercussion on increases in these prices, an aspect which has a negative influence on the company's attractiveness in the marketplace.

Finally, in the devised model, the perception of the demand for consultants will establish the number of junior and senior consultants required, in accordance with the percentage allocation established by the company, which will then either activate its consultant selection and recruitment processes, or departure and redundancy flows.

\section{Results and discussion}

Having validated the functioning of the simulation model devised, we then evaluated certain operational policies with regard to various scenarios for the sectorial demand of consultants, based on the following initial proposition: while external demand for consultancy services conditions the number of consultants (junior and senior) required within the sector as a whole, the different human resources policies implemented will determine the internal capacity enjoyed by each organization to create and maintain its intellectual capital and competitivity within the sector.

In order to validate this statement, we established a series of hypotheses to express the effect of certain measures on the intellectual capital of an organization.

Hypothesis An increase in the investment in training per employee above the average for the sector reduces the internal promotion time required in order for a junior consultant to acquire the intellectual capital necessary in order to take on senior consultant functions, and facilitates the internal flow of junior promotion candidate consultants to the senior category through processes of internal promotion. On the contrary, a reduction in the investment in training per employee below the average for the sector will increase internal promotion time, impeding the flow of consultant promotion, and forcing the company to depend on the external selection of senior consultants.

In order to validate this hypothesis, we considered a scenario of growing sectorial demand for consultants with occasional peaks, during which the organization assumes a prudent policy (highly sensitive to decisions but less sensitive to objectives) and an investment in training either $25 \%$ higher than the average for the sector $(\mathrm{H} 2 \mathrm{~A})$ or $25 \%$ lower than the average $(\mathrm{H} 2 \mathrm{~B})$.

The results of the simulation (Fig. 2) showed that in the former case (H2A), the promotion time required for an inexperienced junior consultant to acquire the skills required for the higher category falls from 36 months (average promotion time for the sector) to 24 , allowing the company to generate a greater number of junior internal promotion candidate consultants, and so avoid dependence on the external selection of consultants to meet demand. On the contrary, the simulation of an investment in training per employee lower than the average for the sector $(\mathrm{H} 2 \mathrm{~B})$ reveals an increase in promotion time from 36 to 48 months, thereby reducing the rate of professional development of consultants, leading to a greater dependency on 

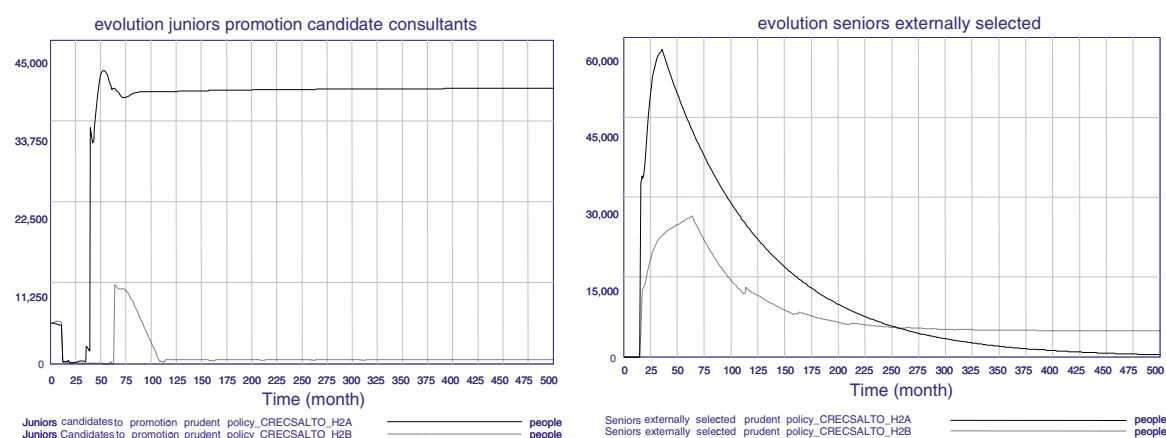

Fig. 2 Changes of the number of junior promotion candidate consultants and seniors externally selected caused by different training investments

external selection processes for senior consultants in the light of a scenario of growing demand, along with a fall in the attractiveness of the company within the marketplace.

Hypothesis The lack of flexibility on the part of the organization in terms of rapidly adjusting its consultant workforce to that demanded by the market at any given time encourages a loss of the internal capital of experienced consultants, and also a fall in the company's competitiveness within the marketplace. On the contrary, the structuring of policies to give the organization the flexibility to make rapid adjustments to its workforce in accordance with market demands encourages the maintenance of its intellectual capital, and also increases the company's competitiveness on the marketplace.

In order to validate this affirmation, a scenario of cyclical sectorial demand was devised, in which the lack of flexibility on the part of the organization was parameterized through the implementation of a moderate policy (highly sensitive to decisions and less sensitive to objectives) and a greater time for the selection of consultants, without maintaining an adequate initial availability of candidates (H3A), while flexibility was identified through the implementation of an aggressive policy (highly sensitive to decisions and objectives) and the maintenance of a lower time for selection and greater percentage of surplus candidates in the recruitment process (H3B).

The results of the simulation (Fig. 3) showed that the internal capacity to generate junior consultants suitable for internal promotion slows down in the face of inflexible conditions (H3A), reducing the figure of actual promotions to senior consultant as a result of internal selection, as well as the company's level of attractiveness within the sector. On the contrary, measures tending to encourage the organization's flexibility to adjust the flow of its professionals to demand (H3B) improve the company's internal capacity to develop its consultants internally within the period established, leading to a lower rate of consultant departure, and also a lower workload, with a positive effect of increasing the attractiveness of the company within the marketplace. 


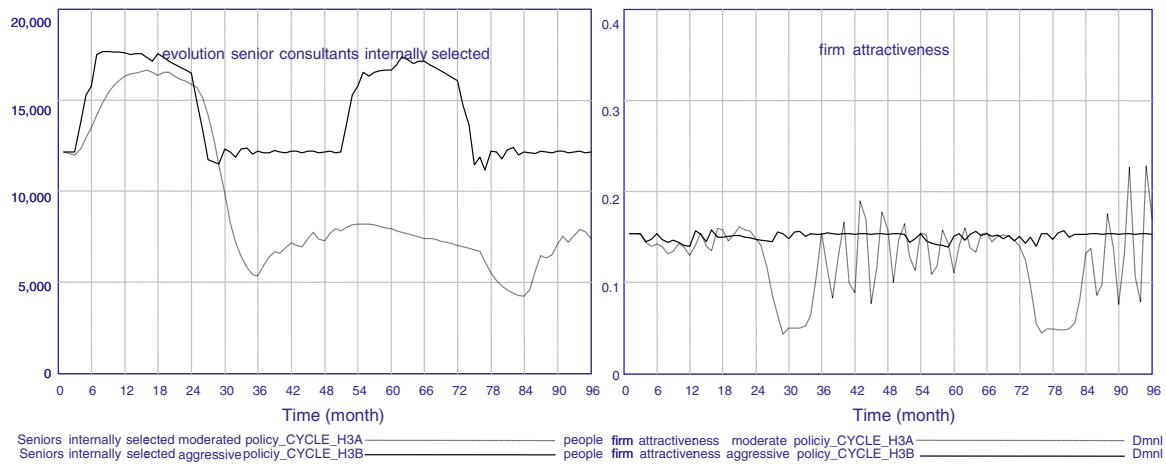

Fig. 3 Changes of the figure of actual promotions to senior consultants and firm attractiveness in a cyclical scenario of sectorial demand

Finally, with regard to the effect of salary policy on maintaining the intellectual capital at a consultancy organization, the following statement was considered:

Hypothesis The number of inexperienced junior consultants and senior consultants departing increases if the salary policy is lower than that appropriate for the company's reputation level within the sector. On the contrary, the number of departures falls with a salary policy higher than that appropriate for the company's reputation level within the sector.

In order to validate this Social capital and Organizational Commitment, we considered a scenario of a growing demand for consultants with occasional peaks, in which the company develops a moderate policy (low sensitivity to decisions but highly sensitive to objectives), maintaining a salary level $25 \%$ lower than that appropriate to its reputation within the sector $(\mathrm{H} 4 \mathrm{~A})$, or $25 \%$ higher than this level (H4B).

A simulation of both effects (Fig. 4) reveals that, while the number of inexperienced junior consultants departing increases considerably if salary levels are lower than those demanded by the level of the company's reputation within the sector (H4A), the number of junior promotion candidates consultants departing is not so sensitive to changes in the salary level, since their behavior is also influenced by a greater generation of vacancies at senior level.

In light of the analysis performed, the following recommendations were established as the final conclusions of the study:

- The proper management of the internal flow of professionals from junior to senior category through a make system of human resources (Miles and Show 1984) involves a need to maintain a level of investment in training per employee which is similar to or higher than the average for the consultancy sector. The converse will tend to cause an increase in departures through a failure to meet the expectations of professionals in terms of development, with an impact on the reputation and attractiveness of the company within the marketplace.

- The implementation of policies allowing the flow of consultants to be adjusted to market demand during any given period will allow the company to reduce the 

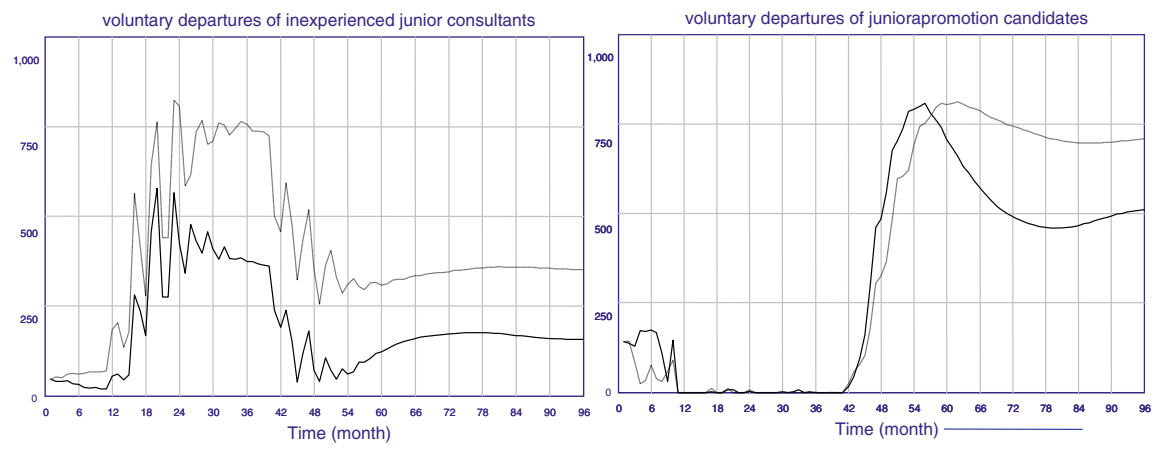

abandonment of inexperienced juniors : moderated policy CRECSALTO HAA
abandonment of inexperienced juniors : moderated policy CRECSALTO_H4B

people/month abandonment juniors promotion candidates : moderated pollicy_CRECSALTO_HAA

Fig. 4 Changes in voluntary departures of inexperienced junior consultants and junior promotion candidate consultants caused by different salary policies

loss of intellectual capital as a result of the departure of its experienced professionals, and also to maintain greater control on its attractiveness as a "knowledge organization" within the marketplace.

- A consultancy organization can temporarily maintain a salary level lower than that appropriate to the level of the company's reputation within the sector, maintaining those professionals who are most profitable in terms of intellectual capital within the organization, if the growth in the demand for consultants guarantees generation of enough vacancies to arrest the rate of departure of junior promotion candidate consultants.

As an overall result of the analysis performed, we may state that, while the external demand for consultancy services determines the number of consultants required within the sector as a whole, the knowledge management policies of each organization determine its internal capacity to create and maintain its intellectual capital and competitiveness within the sector. To this end, the design of a simulation model represents a useful tool to support the decision-making process at executive level.

\section{References}

Amit, R., \& Shoemacker, P. J. H. (1993). Strategic assets and organizational rent. Strategic Management Journal, 14, 33-46.

Andersson, F., Brown, C., Campbell, B., \& Chiang, H. (2005). The effects of HRM practices and R\&D investment on worker productivity. Annual Meeting Sloan Industry Studies (December 14-16).

Barney, J. B. (1991). Firm resources and sustained competitive advantage. Journal of Management, 17(1), 99-120.

Biswas, S., \& Twitchell, D. (1991). Management consulting. A complete guide to the industry. New York: Wiley.

Bonache, J., \& Cabrera, A. (2005). Dirección de personas. Prentice Hall: Financial Times.

Boxall, P. (2006). The strategic HRM debate and the resource-based view of the firm. Human Resource Management Journal, 6(3), 59-75.

Bueno Campos, E., \& Morcillo Ortega, P. (2002). Enfoques principales de dirección del conocimiento: una síntesis. Boletín Intellectus, Centro de Investigación sobre la Sociedad del Conocimiento, $12-15$. 
Calvo, N. (2011). Is the contraction of demand an excuse for the laissez-faire human resource practices at professional services companies? System Dynamics Review, 27(3), 294-312.

Cap Gemini Ernst \& Joung (1999-2005). Annual Report.

Cappelli, P., \& Crocker-Hefter, A. (1996). Distinctive human resources are firm's core competences. Organizational Dynamics, 24(3), 7-22.

Collings, D. G., \& Mellahi, K. (2009). Strategic talent management: A review and research agenda. Human Resources Management Review, 19(4), 304-313.

Dierickx, Y., \& Cool, K. (1989). Asset stock accumulation and sustainability of competitive advantage. Management Science, 35, 1504-1511.

Fèdération Européenne des Associations de Conseils en Management (FEACO). Survey of the European Management Consultancy Market (1998-2005).

Forrester, J. W. (1961). Industrial dynamics. Cambridge: The MIT Press.

Godbout, A. J. (2000). Managing core competences: The impact of knowledge management on human resources practices in leading-edge organizations. Knowledge and Process Management, 7(2), 76-86.

Grant, R. M. (1996). Toward a knowledge-based theory of the firm. Strategic Management Journal, 17 (winter special issue), 109-122.

Hatch, N. W., \& Dyer, J. H. (2004). Human capital and learning as a source of sustainable competitive advantage. Strategic Management Journal, 25(1), 1155-1178.

López-Cabrales, A., Pérez-Luño, A., \& Valle Cabrera, R. (2009). Knowledge as a mediator between HRM practices and innovative activity. Human Resource Management, 48(4), 485-503.

Martell, K., \& Carroll, S. (1995). Which executive human resource management practices for the top management teams are associated with higher firm performance? Human Resource Management, 34, 497-512.

Miles, R. E., \& Show, C. C. (1984). Designing strategic human resource systems. Organizational Dynamics, 31(1), 36-52.

Minbaeva, D. (2008). HRM practices affecting extrinsic and intrinsic motivation of knowledge receivers and their effect on intra-MNC knowledge transfer. International Business Review, 17(6), 703-713.

Nonaka, S., \& Takeuchi, H. (1995). The knowledge-creating company. New York: Oxford University Press, Inc.

Oliva, R. (1995). A Vensim module to calculate summary statistics for historical fit. Cambridge: Systems Dynamics Group, MIT. Memo D-4584.

Peteraf, M. A. (1993). The cornerstones of competitive advantage: A resource-based view. Strategic Management Journal, 14(3), 179-191.

Rumelt, R. P. (1984). Towards a strategic theory of the firm. In R. B. Lamb (Ed.), Competitive Strategic Management (pp. 556-570). Englewood Cliffs, New Jersey: Prentice Hall.

Rynes, S. L., Gerhart, B., \& Minette, K. A. (2004). The importance of pay in employee motivation: Discrepancies between what people say and what they do. Human Resource Management, 43(4), 381-394.

Senge, P. M. (1990). The fifth discipline. México: Granica.

Stearman, J. (1998). Appropriate summary statistics for evaluating the historic fit of the system dynamics models. Dynamica, 10, II.

Stearman, J. (2000). Systems thinking and modeling for a complex world. Boston: Irwin McGraw-Hill.

Subramony, M. (2009). A meta-analytic investigation of the relationship between HRM bundles and firm performance. Human Resource Management, 48(4), 745-768.

Tarique, I., \& Schuler, R. S. (2010). Global talent management: Literature review, integrative framework and suggestions for further research. Human Resources Management Review, 45(2), 122-133.

Top Consultant. (2007). Retention Report 2007. A key challenge for the management consultancy sector. UK Top-Consultant.com and Zambeasy.com.

Walton, R. E. (1985). From control to commitment in the workplace. Harvard Business Review, 63(2), 77-84.

Warren, K. (2000). The softer side of strategy dynamics. Business Strategy Review, 11(1), 45-58.

Warren, K., \& Kourdi, J. (2003). People power. Developing the talent to perform. London: Vola Press.

Watson, G. W., \& Papamarcos, S. D. (2002). Social capital and organizational commitment. Journal of Business and Psychology, 16(4), 537-551.

Wright, P. M., \& McMahan, G. C. (1992). Theoretical perspectives for strategic human resource management. Journal of Management, 18(2), 295-320. 